\title{
LIVSHISTORIER SOM GRUNDLAG FOR VÆRDIGHEDSGENERERENDE PRAKSIS?
}

\author{
LENE TEGLHUS KAUFFMANN OG ULLA SKJØDT
}

Denne artikel handler om, hvordan begrebet livshistorie kan få betydning for værdighed i pleje og omsorg af den ældre, der lever med demens på et plejecenter, og dermed for, hvordan den ældre bliver mødt i sin aktuelle livssituation. Begrebet er ikke nyt i forhold til værdig pleje og omsorg (Bjelland 2014; Brownie \& Horstmanshof 2012; Cooney \& O'Shea 2019; Moyle et al. 2011), men på de to plejecentre i Danmark, hvor vores feltarbejde foregik, er nye projekter om livshistorier blevet gennemført i relation til de såkaldte værdighedsmidler, der har til formål at understøtte en værdig ældrepleje. Som en medarbejder på et plejecenter i vores undersøgelse forklarer:

Der kom nogle millioner ud til kommunerne, og så skulle alle kommuner lave en værdighedspolitik. Og det har vi så arbejdet med her på den måde, at vi har haft konsulenter på. Vi har arbejdet med værdigheden som sådan, og der har vi så konkret taget fat på livshistorierne.

Livshistorier er altså også en del af en større fortælling, idet værdighed i pleje og omsorg for ældre synes at være blevet et emne, der har politisk bevågenhed (Sundhedsstyrelsen 2017). I 2019 har Sundhedsstyrelsen oprettet et Videnscenter for værdig ældrepleje, som arbejder for at sikre sårbare ældre og deres pårørende en værdig alderdom. Hovedparten af beboerne på plejecentre i Danmark i dag lever med demens (Gjødsbøl, Koch \& Svendsen 2017; Skjødt 2016), og plejen og omsorgen for dem løftes primært af pleje- og omsorgspersonale, der er uddannet som social- og sundhedshjælpere og -assistenter. Derudover kan ergoterapeuter, demenskonsulenter og sygeplejersker være tilknyttet de enkelte boenheder i mindre grad (Skjødt 2016). Demenssygdommen er oftest ganske fremskreden, når først der visiteres til en plejebolig, da man skal have behov for omfattende eller fuldstændig pleje for at blive tildelt en plejebolig (ibid.). 
I demenshandlingsplanen fra 2017 bliver værdighed præciseret som: „,. den enkelte, der lever med demens, og dennes pårørende skal mødes af en indsats af høj faglig kvalitet, som bygger på værdighed, medmenneskelighed og respekt for den enkeltes ønsker, behov, ressourcer og for personen bag ved sygdommen“ (Sundheds- og Ældreministeriet 2017:5). Livshistorier kan, som vi skal se, forstås som et svar på denne politiske dagsorden om, hvordan værdighed kan fremmes, men planen rummer ikke et konkret svar på, hvad der konkret forstås ved værdighed. Det synes dog forbundet til den forståelse af demens, der udtrykkes på en fin måde i et citat i publikationen: „Jeg er Jens med demens, men jeg er også Jens imens" (op.cit.2). I lyset af disse politiske perspektiver bliver det interessant at se nærmere på sammenhængen mellem livshistorier og værdighed i praksis.

I feltarbejdet var vi som udgangspunkt optaget af, hvordan en anden politisk ambition udspiller sig, nemlig hvordan såkaldte velfærdsteknologier kan understøtte livskvalitet for beboere og arbejdstilfredshed for pleje- og omsorgsmedarbejdere på plejecentre (Kauffmann \& Rosager 2019), og vores fokus var således i udgangspunktet ikke på hverken livshistorier eller værdighed. Men i vores fordybelse i det empiriske materiale blev det klart, at livshistorier synes at blive forstået som en slags ,quickfix“ til værdighed, og at værdighed er blevet en begrebsliggørelse af målsætningen for omsorgens praksis. Dermed kom vi til at anskue livshistorien som en slags teknologi, en materialitet, som potentielt får betydning i relationen mellem den professionelle og personen, der lever med demens. ${ }^{1}$

Hasse og Wallace (2014) taler om omsorgsteknologi som en betegnelse for de teknologier, der anvendes i omsorgen for ældre i hjemmet og på plejecentre, fx alarmer, sensorteknologi og sociale hjælperobotter (op.cit.83) - alle de teknologier, som vi var optaget af i vores undersøgelse. Hasse og Wallace inkluderer ikke livshistorier på deres liste. Men livshistorien skal ligesom mange „artefakt"teknologier understøtte omsorgen, og den får sin værdi gennem samspillet mellem pleje- og omsorgsmedarbejdere og personen, der lever med demens. På den måde kan livshistorien betragtes på lige fod med andre teknologier, der former omsorgen. Men hvordan kan livshistorier bidrage til at skabe værdighed for personer, der lever med demens, og hvad betyder værdighed egentlig i denne sammenhæng? Det er dette spørgsmål, vi er optaget af. Dermed bliver teknologiperspektivet i nogen grad henvist til baggrunden, selv om det som bagtæppe skinner igennem i analysen. Til sidst samler vi dette perspektiv op og trækker det frem i forgrunden.

Formålet med artiklen er dermed at diskutere den øgede interesse for livshistorier som en transformation af omsorgen i en retning, hvor værdighed potentielt skabes, og hvordan denne transformation afføder, at sygdommen demens og de 
personer, der lever med den, potentielt bliver til på nye måder. Artiklen er bygget op af et kort afsnit om det teoretiske udgangspunkt for at forstå livshistorier i relation til værdighed, efterfulgt af et afsnit om kønskategorisering som identitetshåndtering, som viser, hvordan identitetshåndtering kan foregå på, hvad man kunne kalde kategoriseringsniveau. Derefter følger fire analytiske afsnit med forskellige perspektiver på livshistorien. Det første viser, hvordan også livshistorien kan resultere i en relativt overfladisk identitetshåndtering, hvor livshistorien forstås som et aftryk af personen, der lever med demens. Det næste afsnit ser nærmere på, hvordan livshistorien kan bidrage til hukommelsesterapeutiske tiltag, der åbner for en virkelighedskonstruktion, hvor fortiden spiller en mere aktiv rolle i nutiden. Dernæst ser vi nærmere på ideen om stjernestunder som en identitetshåndtering, der bevæger sig mellem det opgavecentrerede og det personcentrerede perspektiv. Til sidst ser vi på livshistorien som en mere dynamisk virkelighedskonstruktion, inden vi i konklusionen samler teknologiperspektivet op.

\section{Værdighed som identitetshåndtering og virkelighedskonstruktion}

På baggrund af et norsk studie argumenterer Bjelland (2014) for, at formålet med brug af livshistorier er identitetshåndtering, og at de fungerer som en aktiv virkelighedskonstruktion. Det betyder, at individuelle ældre i forskellige kontekster bruger livshistoriske elementer til identitetshåndtering såvel som til etablering af sociale fællesskaber og tilhørsforhold, der hænger sammen med virkelighedskonstruktion. Identitetshåndtering er dermed en selektiv og situeret udvælgelse af fortid som led i strategier for selvrepræsentation, der legitimerer adfærd og skaber kontinuitet i livsforløbet (op.cit.82). Bjellands informanter er ikke personer, der lever med demens, og hendes fokus er heller ikke, hvordan livshistorier anvendes af pleje- og omsorgsmedarbejdere. Men pointen om identitetshåndtering og virkelighedskonstruktion er alligevel interessant i relation til det empiriske grundlag for denne artikel, idet livshistorier og arbejdet med dem udfolder, „hvem personen, der lever med demens, er“. Virkelighedskonstruktion handler her ikke så meget om at indskrive sig i specifikke, sociale fællesskaber, men mere om etableringen af tilhørsforhold i en specifik historisk tid, en generation, og dermed som en forankring i fortiden såvel som i nutiden. Identitetshåndtering er i denne sammenhæng forstået som en opgave for pleje- og omsorgsmedarbejdere snarere end noget, som personen, der lever med demens, skal præstere. Identitetshåndtering kommer her ikke bare til at handle om, at der inddrages historiske elementer i livshistorien, men også om, at der skabes forbindelse mellem fortid og nutid. Denne forbindelse afspejler det, Bjelland taler om som strategier for selvrepræsentation - her kommer det til at handle om strategier for at lade 
personen, der lever med demens, fremstå som andet og mere end det og dermed blive mødt med værdighed.

Værdighed kommer på den måde til at handle om at blive mødt som en person med en historie såvel som en nutid; som et unikt individ og ikke blot en diagnose. Empirien udfolder, hvordan pleje- og omsorgsmedarbejdere må anvende den enkeltes livshistorie for at skabe hans eller hendes identitet her og nu. Det er i dette perspektiv, livshistorier kan komme til at fungere som en slags omsorgsteknologi, der skaber den enkeltes identitet og dermed åbner for værdighed.

Cooney og O'Shea (2019) viser ved en litteraturgennemgang, hvordan det er veldokumenteret, at livshistorier hjælper pleje- og omsorgsmedarbejdere til at se personer, der lever med demens, som individer og ikke blot som kategorier. De uddyber deres fund i litteraturgennemgangen med en analyse af interviews med plejeog omsorgsmedarbejdere om deres erfaring med at anvende livshistorier. Deres fund bekræfter litteraturgennemgangens konklusion om, at produktionen af livshistorier bidrager til det, Kitwood (2009) kalder personcentreret pleje og omsorg (Cooney \& O'Shea 2019:2741). De kommer frem til, at selve processen med at producere livshistorien - livshistoriearbejde - kan være afgørende i forhold til at se personen bag demensen og for, hvordan det lykkes at lade pleje og omsorg tage udgangspunkt i den enkelte fremfor i pleje- og omsorgsrutiner og kategoriseringer.

Vi vil i det følgende diskutere, hvordan livshistorier, når de bliver til i en institutionaliseret form og anvendes som „livshistoriearbejde“ af pleje- og omsorgsmedarbejdere, kan bidrage til værdighed, forstået som identitetshåndtering og virkelighedskonstruktion. Først vil vi dog se nærmere på, hvordan kategorisering udspiller sig i den pleje- og omsorgspraksis, vi fik beskrevet af vores informanter på de to plejecentre, hvor feltarbejdet udspillede sig.

\section{Kategorisering som identitetshåndtering}

Den personcentrerede tilgang (Kitwood 2009) står i pleje- og omsorgsarbejdet med ældre generelt, og dermed også ældre på plejecentre, i naturlig kontrast til en opgavecentreret tilgang, hvor opgaverne primært retter sig mod personlige og praktiske behov som fx personlig pleje og rengøring (Skjødt 2016, 2019). I empirien udtrykkes denne skelnen, når en medarbejder fortæller, at „det sociale“ typisk uddelegeres til uuddannet personale eller frivillige. „Det sociale“ synes at handle om at være sammen med andre, da hun beskriver, at „det sociale“ kan være, når frivillige tilrettelægger en „klub“, hvilket sker én gang om måneden:

De frivillige laver noget, vi kalder klub. Der er en mandeklub med yatzy og dåseøl og en dameklub, hvor der drikkes bobler, lægges neglelak og gives håndmassage [...] Det er jo bare livskvalitet, så det batter, for vores beboere, men det er ikke 
noget, vi [pleje- og omsorgsmedarbejdere] er i stand til at give dem, så altså, hvis hun [den frivillige] ikke gjorde det, så ville de ikke få det [...] Det er noget, der er taget fra os, som det er nu.

I forhold til identitetshåndtering og virkelighedskonstruktion forekommer disse aktiviteter også interessante, idet de kan ses som håndtering af kønsidentitet; der sker en kønskategorisering af den mere stereotype slags. Jenkins (2000) beskriver den slags kategorisering som institutionaliseret og peger på, at ,det er oftest, i hvert fald delvist, en bevidst praksis udført af dem, der kategoriserer" (Jenkins 2000:14; vores oversættelse). Her kan man dog diskutere, om de frivillige, der bliver omtalt af informanten, handler bevidst, når klubben skal fungere på den beskrevne måde, eller om deres praksis snarere er baseret på deres egne, internaliserede kønskategorier.

Med disse stereotype kategoriseringer skriver opgaven med klub sig for så vidt ind i den opgavecentrerede form snarere end den personcentrerede tilgang, på trods af at informanten fortæller om den som noget særligt, noget, der ikke hører under de opgaver, hun og hendes kolleger skal tage sig af. Hvis cafeen skulle være personcentreret, skulle der være plads til en langt mere individualiseret kønskategorisering. Den slags stereotyp kategorisering, som her kommer til udtryk, kan være et uheldigt udgangspunkt for identitetshåndtering, og her bliver det således klart, at livshistorien kan have betydning i forhold til en mere personcentreret og mindre kategoriserende tilgang.

I vores feltnoter beskrives følgende samtale:

En ergoterapeut fortæller, at værdighedsprojektet har betydet, at medarbejderne skulle indsamle livshistorier for at bruge dem $\mathrm{i}$ hverdagen $\mathrm{i}$ forhold til den enkelte beboer. Det har betydet, fortæller hun, at man i en boenhed har skiftet opgavesedlen ud med kort, der beskriver, hvad der er en god dag for den enkelte beboer. For eksempel har en af beboerne ikke lyst til at komme i bad, men vil helst have etagevask, som hun har fået hele sit liv. Ergoterapeuten fortæller videre, at hun har været med til samtalerne med beboerne og sammen med en demensspecialist spurgt til, 'hvad er en god dag' for den enkelte. Hun fortæller eksempler fra dette arbejde, heriblandt hvordan en af beboerne har sagt, at hun har skrællet nok kartofler i sit liv, så hun vil helst være fri, hvis det skal være en god dag.

Eksemplet om kvinden, der har skrællet kartofler nok i sit liv, er interessant i lyset af kønskategorisering, idet husarbejde ofte ses som en meningsfuld aktivitet for kvinder. Hun får fortalt, at hun ikke vil skrælle flere kartofler i sit liv, og dermed undslipper hun i et givent omfang den stereotype kønskategori, i hvert fald i forhold til kartoffelskrælning.

Sådanne kønsstereotyper kan være svære at undslippe, når man ikke længere rigtigt kan svare for sig selv. En viden om personen bag demensdiagnosen, som 
den kommer til udtryk i fortællingen om en god dag, er tydeligvis afgørende for, at man kan finde aktiviteter eller som i dette tilfælde lade kvinden nyde, at andre skræller kartofler, mens hun ser på. Så mødes den enkelte ældre, der lever med demens, i sin egen ret.

Spørgsmålet er dog, om livshistorien kan afløse stereotyper om køn, især hvis en kvinde ikke kan forklare, at hun ikke længere har lyst til at skrælle kartofler, eller hvis hun nogle gange har lyst og andre gange ikke har lyst. Med denne anvendelse af livshistorien er der også en risiko for, at pleje- og omsorgspersonalet kommer til at tage et billedligt udsagn for pålydende og gøre det abstrakte for konkret.

Som citatet viser, skal livshistorien resultere i en identifikation af, hvad der er en god dag for den enkelte, hvilket så skal noteres på kort, som skal erstatte opgavesedlerne. Selv om det ikke uddybes i interviewet, hvordan det lader sig gøre, kommer det til at fremstå ret konkret, hvordan anvendelsen af livshistorier kan ses som en anledning til at indrette omsorg og pleje mere personcentreret. Livshistorien er således ikke bare en historie om den enkelte, men et begreb, der potentielt står for det ,rigtige“ udgangspunkt for organisering af pleje og omsorg til den enkelte. Derfor er det interessant at se nærmere på, hvordan livshistorien italesættes af pleje- og omsorgsmedarbejdere, pårørende, demensspecialister og ledere. Det er denne empiri, de følgende afsnit tager udgangspunkt i.

\section{Livshistorien som et aftryk af en historisk person}

De livshistorier, vi stødte på i feltarbejdet, er et skriftligt dokument om livet, der går forud for sygdommen, ofte suppleret med billeder. De kan handle om fakta såsom børn, bolig og tidligere erhverv, men også om særlige begivenheder i livet, fx bryllup eller børnebørns fødselsdage og interesser og vaner. Alt sammen udgør en slags historiske fakta, hvad enten de er individuelle eller af mere kollektiv karakter som fx 2. verdenskrig. De nedskrives ofte med hjælp fra de pårørende, idet personer, der lever med demens, sjældent selv er i stand til at bidrage fuldt ud til den. Livshistorier opbevares på forskellige måder som fx i en mappe i den enkeltes bolig, på en iPad og/eller i computerens „CARE“-system på kontoret.

På de to plejecentre, der indgik i vores projekt, fandt vi livshistorier på den enkeltes stue; det ene sted i en mappe og det andet sted på en iPad. Indholdet var forskelligt og kunne være både tekst og billeder, men det var altid historisk. Med iPad-modellen var det svært for beboeren selv at åbne den, idet mange af de ældre ikke er rutinerede i anvendelsen af moderne digitale teknologier. Mappen var lettere tilgængelig og kunne anvendes af fx os, når vi talte med de ældre $\mathrm{i}$ deres bolig. Vi kunne med mappen i hånden bladre og se billeder og ud fra dem spørge ind til deres liv. 
Det historiske aspekt af livshistorien har betydning for den enkelte ældre på forskellig måde, som det kommer til udtryk i nedenstående citat:

Det er vigtigt med en rigtig god livshistorie. Demente kan ikke sætte ord på, hvad det er, de måske er bange for. Eller hvad det er, de ser. Fordi mange demente har også hallucinationer. Og der er det en rigtig god idé at vide, om de har haft en kat. Har de boet i en 1-værelses lejlighed i en baggård i København? Har de levet under krigen? Det giver rigtig god mening. For så kan man altså sige: Det behøver du ikke at være bange for, fordi jeg er lige her. Så det giver rigtig stor tryghed, at man kender folks livshistorie.

Dette udsagn peger på, at kendskab til den enkeltes livshistorie kan føje noget til opfattelsen af vedkommende. Kendskab til en persons fortid giver et billede af, hvem han eller hun er - eller måske rettere var - og åbner tilsyneladende for en forståelse af, hvad han eller hun kan være bange for. Som nævnt peger Bjelland (2014) på, at livshistorien er en virkelighedskonstruktion for de personer, der indgår i hendes studie. Når personer, der lever med demens, oftest ikke selv er i stand til at konstruere livshistorier som strategier for selvrepræsentation, og livshistorien bliver konstrueret og fortolket af andre, bliver virkeligheden for så vidt konstrueret af pleje- og omsorgsmedarbejdere, som ønsker at forstå, hvem personen, der lever med demens, er. Den historisk forankrede identitet bliver således fortolket i en specifik sammenhæng, hvor den tjener bestemte formål, herunder at forstå reaktioner og handlinger i nutiden, som her med formålet at skabe tryghed.

På baggrund af feltarbejde på et plejecenter beskriver Anne Kerstine Nielsen (2015), at pleje- og omsorgsmedarbejdere ser det at bevare eller vedligeholde identiteten som en vigtig arbejdsopgave, og hun peger på, at livshistorien er et „sted“, hvor personens ,,autentiske selv“ kan findes. Med begrebet om autenticitet trækker hun på filosoffen Charles Taylor, der argumenterer for, at en sammenhængende livshistorie, hvor fortid, nutid og fremtid bindes sammen til en meningsfuld historie, spiller en afgørende rolle for konstruktionen af det autentiske selv (op.cit.14). Med livshistorien, som den formes i denne specifikke kontekst, er der dog fokus på fortid og ikke så meget nutid - og slet ikke fremtid.

Alligevel får vi i citatet indtryk af, at livshistorien medvirker til at fastholde identiteten eller det autentiske selv, $\mathrm{i}$ hvert fald $\mathrm{i}$ et vist omfang, når der $\mathrm{i}$ citatet peges på, hvordan fortiden er en del af den enkeltes historie. Ifølge Jenkins (2000) handler identitet både om den personlige og den sociale identitet, hvor den personlige identitet kun delvis er i vores egen magt; vi er som personer også underlagt andres kategoriseringer. Jenkins (2000) er hovedsageligt optaget af, hvad han kalder social identitet, og i lyset af, at de personer, vi her ser nærmere på, ikke har styrke til at fastholde deres autentiske selv gennem selvrepræsentation, bliver det relevant at fokusere på netop livshistorien som forbundet til den sociale identitet. 
I den sociale identitet ligger naturligvis et magtaspekt, der handler om, hvem der har ret eller magt til at definere en given situation. Denne ret eller magt bliver afgørende for, hvilke identiteter der er mulige (op.cit.9). Dermed handler det ikke blot om, hvad der står i livshistorien, men også om, hvordan livshistorien kategoriserer personer, der lever med demens.

Jenkins (2000) taler om en primær og sekundær form for social kategorisering og skitserer en lang række kontekster for den. Den primære socialisering er den, der præger barndommen og relationen mellem barnet og de voksne. Men også andre sociale relationer udspiller sig på lignende måde, hvor nogen har retten til at kategorisere andre, fx i diagnosticering af demens og i legitimering af interventioner i relation hertil. Også de stereotype kønskategoriseringer, vi diskuterede ovenfor, kunne ses som et udtryk for denne slags kategorisering. I lyset heraf bliver livshistorien og de fakta, den indeholder - køn, ægteskabelig status, tidligere erhverv og boligforhold samt elementer af kollektive historiske begivenheder - en kategorisering, der tegner et aftryk af mennesket i centrum af vores kollektive historie. Dermed er der fokus på, at såkaldte ydre faktorer og kategoriseringer, som de udspiller sig her, bidrager til en virkelighedskonstruktion, hvor historiske fakta har konsekvenser for, hvem man kan være, og hvilke sammenhænge der kan trækkes på i identitetshåndtering.

I artiklen „De skrev hende ned“ beskriver Simonhjell og Hellstrand (2019), hvordan struktur og format af det, de kalder livsarket (en norsk udgave af livshistorien), bestemmer, hvordan fortællingen bliver formidlet. Det har betydning, hvem der forfatter livshistorien, om det fx er en ægtefælle, børn eller venner, og også i hvilken form den bliver til. Simonhjell og Helstrand pointerer, at fortællinger og viden forbundet til fortællingen altid er situeret, idet både fortælleren og de begreber og diskurser, der former fortællingen, vil have betydning (op.cit.7).

I lyset heraf giver det mening at udvide begrebet om „livshistoriearbejde“, så det ikke kun handler om, hvordan livshistorien bliver til, men også om, hvordan den får betydning $i$ en situeret praksis, og hvordan den afspejler bagvedliggende forståelser eller diskurser. Citatet ovenover viser, at frygt kan hænge sammen med historiske begivenheder. Livshistorien bliver dermed et bidrag til at forme en nutid med fortidigt indhold for personen, der lever med demens. Virkeligheden konstrueres således på måder, der trækker fortiden ind i nutiden og åbner for, at den danner rammen for fortolkningen. Fortiden bliver dermed determinerende for den identitetshåndtering, der kan finde sted, og for, hvem man kan være i den aktuelle nutidige situation.

Pårørende er ofte involveret $i$ at få livshistorien ,„på plads“, som en demensspecialist forklarer: 
Ja, de pårørende er ofte med til at få skrevet livshistorien ned. Også for at hjælpe borgerne til at sætte ord på, hvad er der sket. Det er lige fra starten af, hvor de er blevet født henne, hvor mange har de været i børneflokken, hvornår er de blevet gift, hvornår har de fået børn, hvad har de lavet, hvor har de boet henne, interesser, sjove episoder, kaldenavne. Hele baduljen. Simpelthen det hele.

Her fremgår det, hvordan pårørende involveres i tilblivelsen af livshistorien. Flere af de pårørende, der var informanter i vores undersøgelse, fortalte ligeledes, hvordan de havde bidraget til livshistorien, som følgende uddrag fra et interview viser:

I: Skulle I beskrive din mors livshistorie?

R: Ja. Det var min far, der gjorde det. Ja, jeg sagde til ham, at det synes jeg, han skulle gøre. Fordi han havde jo mere styr på det, end jeg havde, ikke? Det synes han var vældig spændende, så han havde skrevet op og ned. Så han var forberedt! (Griner hjerteligt).

Vi ser her, hvordan moderens livshistorie har været et vigtigt anliggende for faderen, men også, at det var vigtigt at „have styr på det", hvilket indikerer, at der er én historie, som er den rigtige. På den måde bliver historien måske hovedsagelig faktaorienteret, som også demenskoordinatorens udtalelse indikerer.

Gjødsbøl og Svendsen (2019) taler om usammenhængende personlighed (,,discontinuity in personhood“) som noget, de pårørende tilskriver familiemedlemmet, der lever med demens. Med dette begreb påpeger de, at for den pårørende bliver han eller hun til to-i-en, så at sige; den, der var før, og den, der er nu, som adskilte dele (op.cit.53). Vores empiri ovenfor indikerer, at denne usammenhængende personlighed også præger medarbejdernes pleje- og omsorgsperspektiv, da det er ,hele baduljen“ fra tiden før, som er i fokus i livshistorien. I lyset af dette bliver det autentiske selv, som vi med reference til Nielsen (2015) har omtalt ovenfor, udfordret, idet autenticiteten netop er knyttet til en sammenhæng mellem fortid, nutid og fremtid.

Den pårørende til den person, der lever med demens, ser, hvordan sygdommen ændrer vedkommende, og når indflytning i plejebolig bliver aktuelt, er ændringerne oftest radikale, ligesom også deres indbyrdes relation er ændret (Pedersen 2018). Ved at lade den pårørende føre ordet $i$ tilblivelsen af livshistorien er der således et næsten naturligt fokus på den, der var før, som noget andet end den, der er nu. Hvis livshistorien så tilmed bliver til som fakta, er der ikke fokus på betydningen for den enkelte af de begivenheder, der kommer til at forme livshistorien. Tiden kommer til at stå stille, så at sige, og den virkelighed, der konstrueres, formes hovedsageligt af fortiden. 


\section{Livshistorie og hukommelsesterapi}

Livshistorie er ikke bare en fortælling om et liv, der gik forud, men en fortælling, der tjener et ganske bestemt formål, nemlig at fremme værdighed. Med dette fokus bliver det interessant at se nærmere på, hvordan forskellige aktiviteter udgør en del af det, vi er optaget af her som identitetshåndtering og virkelighedskonstruktion.

En af de pårørende, vi interviewede, fortalte med glæde om, hvordan personalet havde gjort det til en vane at tænde for musikken i hendes ægtefælles bolig, da hun havde oplyst, at hendes mand var glad for musik i sit tidligere liv. Mandens interesse for musik tidligere er grunden til, at han holder af at lytte til det også nu, hvor han lever med demens, og det er også den forbindelse, den pårørende etablerer. Musik er kendt som en sansestimulering, der kan bringe ro til personer, der lever med demens, og som bliver agiterede (Craig 2014). Forskningen på dette område peger på, at musik, der er velkendt, synes at have en bedre effekt end ukendt musik. For eksempel beskrives det, at selv rolig barokmusik kan have den modsatte effekt, altså forårsage rastløshed, aggressiv adfærd, vredladenhed og svigtende hæmninger, hvilket henviser til betegnelsen agitation (Vink et al. 2013). I lyset af dette kan viden om lige præcis musikpræferencer være en vigtig del af livshistorien.

I relation til den enkelte kan livshistorien anskues som en slags hukommelses- eller sanseterapi; den kan hjælpe et menneske, der i et eller andet omfang har mistet hukommelsen som resultat af sygdommen, med at finde sin ,autenticitet" ved at skabe forbindelsen mellem fortid og nutid (og fremtid). Mileski et al. (2019) har udarbejdet et kvalitativt review om sensorisk og hukommelsesterapi i plejen af personer, der lever med demens. De argumenterer for, at den slags terapi har en positiv effekt på personer, der lever med demens, som bliver mindre urolige og aggressive, mindre vandrende og dørsøgende og bedre til at indtage føde. I eksempler, hvor fortiden kan gøre, at personen, der lever med demens, bliver bange i en given situation, er det ikke helt klart, hvordan viden om den enkeltes fortid helt konkret kan bidrage til at skabe tryghed. Men i lyset af eksemplet med musikken her og i øvrigt ifølge Mileski et al. (ibid.) synes det at kunne trække fortiden ind i nutiden at være en anerkendelse af selve forbindelsen mellem fortid og nutid.

Musikken i sig selv skaber dog potentielt mere end en forbindelse mellem fortid og nutid. Tyler (2017) har beskæftiget sig med kunst som et „rum“, hvor personen, der lever med demens, kan være i dialog med sin omverden på alternative måder. Det rationelle og sproglige forsvinder måske, men som hun forklarer gennem sin analyse af pårørendes rolle i det, hun med henvisning til Mattingly kalder moralske laboratorier, er der en anden mulighed end at vende ryggen til, når 
de almindelige former for kommunikation forsvinder (op.cit.286). Hun beskriver en lang række initiativer rettet mod personer, der lever med demens, fx kunstmaling, og viser, hvordan de åbner for andre udtryk. Hun refererer til Batting, en anden amerikansk demensforsker, der hævder, at kunsten tilbyder måder at skabe meningsfuldhed på i livet for personer, der lever med demens, og som $\mathrm{i}$ et medicinsk perspektiv anses for liv uden mening (op.cit.287). Musikken eller andre kunstarter åbner for forbindelser eller relationer, hvor det bliver muligt for en person, der lever med demens, at udtrykke sig på nye måder. I lyset af dette bliver musikken endnu mere vigtig, ikke bare som fortiden, der skaber en ramme om nutiden og dermed en hukommelsesterapi, men også som en mulighed for at skabe mening i den enkeltes liv. Det kræver et personcentreret snarere end et opgavecentreret perspektiv og en åbenhed at finde ind til den enkelte, lige her og nu. Vi skal se nærmere på livshistorien i forhold til den personcentrerede tilgang nedenfor.

\section{Livshistorien som grundlag for stjernestunder}

Lederen på et af de plejecentre, der indgik i vores undersøgelse, talte i et interview om værdighedspolitik og livshistorier i relation til, hvad hun kalder stjernestunder:

I relation til værdighedsmidlerne har vi taget livshistorier på alle beboerne og fundet ud af, hvad der er en stjernestund for dem. Og det har faktisk været en øjenåbner. For der var $\mathrm{fx}$ en, hvor det bedste, der kunne ske for hende, var, hvis hun kunne få lov at gå rundt i morgenkåbe - du ved, til klokken 11 eller sådan noget i den stil. Eller at en kunne få lov at få en Baileys klokken 8 om aftenen - eller hvad det kunne være. Det er sådan nogle små bitte ting! Og det har vi nu fået skrevet ned, sådan at vi er i stand til at fortælle hinanden - også når der kommer en ny eller en anden en - det er dét, der er livet for hende.

Her kommer livshistorien altså til at være grundlaget for, at pleje- og omsorgspersonalet kan skabe „stjernestunder“; arbejdet med livshistorien har givet dem indsigt i, hvad der betyder noget for den enkelte. Gjødsbøl og Svendsen (2019) har ligeledes fokus på stjernestunder og peger med begrebet på en stund, hvor personen, der lever med demens, udtrykker en form for velvære eller tilfredsstillelse som respons på interaktionen med personalet. På den måde bliver deres udlægning en lidt anden end den, der kommer til udtryk i citatet.

At tillade en beboer at gå rundt i morgenkåbe til kl. 11, hvis det er det, hun foretrækker, kræver, at organiseringen af pleje og omsorg kan tage hensyn til den enkelte. Skabelsen af stjernestunder synes dermed at kræve en dedikeret indsats såvel som tid og konkurrerer med opretholdelsen af den skematisk organiserede, 
standardiserede og opgavecentrerede tilgang (Skjødt 2019, 2020). Derudover er eksemplet interessant, fordi lederen taler om stjernestund på en bestemt måde; en måde, der som nævnt adskiller sig fra Svendsen et al. (2018), som har udført feltarbejde på et plejecenter med fokus på relationen mellem pleje- og omsorgspersonalet og personer, der lever med demens. Begrebet stjernestunder er et empirisk begreb både for os og for dem, som dog således bruges på en anden måde af deres informanter; for dem er det relationelle i fokus.

Når tilladelsen til at gå i badekåbe til kl. 11 i vores eksempel ses som en stjernestund, synes årsagen at være, at livshistorien skal sikre, at personen, der lever med demens, kan opretholde sine vaner, som naturligvis kan være historisk forankrede, men som også er et udtryk for, hvordan hun har det bedst lige her og nu. Dermed kan det anskues som en identitetshåndtering, der rækker ud over kategorier som køn såvel som historiske fakta, som vi diskuterede ovenfor. Her kommer det personlige i spil. Det er altså det personlige, der er centralt i den forståelse af stjernestunder, som informanten her har i spil.

I lyset af spændingen mellem opgavecentreret og personcentreret omsorg er det dog relevant at overveje, om livshistorien som fokuseret på det personlige kan få praktiske pleje- og omsorgsopgaver af den opgavecentrerede type til at blive mere personcentrerede. Følgende uddrag af et interview med en medarbejder kunne umiddelbart tyde på det:

I: Hvad ... Har I så skrevet livshistorien op i en bog eller på en iPad eller i et system på pc'en?

R: P.t. har vi ikke fået noget sådan fast produkt ud af det. Det, vi gerne vil have ud af det, det er, at man har et skilt på døren til deres bolig. Altså, vi har tre ting, som er vigtige for den her person. Det kan være, at man ... du behøver ikke at banke på, for hvis du banker på, så får du et rigtig surt resultat på den anden side af døren. Så det kan være, man bare skal komme med et frisk 'god morgen!' fx. Og det kan også være, at øh ... at de godt kan lide, at vinduet bliver åbnet, eller at de får en kop kaffe, før vi går i gang, eller hvad der nu lige er vigtigt for den her person. Og det er rart at vide for nogle, der er afløsere. Det er rart at vide, når man er ny på afdelingen. Og det er også rart at vide, når man er pårørende, fordi man kan se, de har fokus på, at det er de tre ting, som min mor godt kan lide.

Det bliver her klart, at livshistorien kan risikere at blive reduceret til ,tre ting, der kan stå på en seddel og hænge på døren“. Det kan naturligvis være de vigtigste tre ting, og dermed kan der etableres et udgangspunkt netop for den personcentrerede pleje og omsorg. Men spørgsmålet er, hvordan de tre ting former opgaven ud fra de to kategorier af pleje og omsorg, vi har fat i her. Med tre ting på sedlen som en slags opskrift for, hvordan man skal møde personen bag døren, bliver det, der kunne se ud som et godt udgangspunkt for den personcentrerede tilgang, måske 
til en opgave lidt på lige fod med at give støttestrømper på eller hjælpe med et bad. Hvis bare vinduet bliver åbnet og kaffen serveret, er alt godt. Men i værste fald kan det betyde, at der er mindre grund til at forholde sig til det enkelte menneske, som det fremtræder lige den dag, for man ved jo allerede, hvad der skal gøres. Opgaven bliver dermed standardiseret og kan let passes ind i den opgavecentrerede pleje. Stjernestunder, som Gjødsbøl og Svendsen (2019) beskriver dem med fokus på det relationelle, eller som vi har forstået dem med fokus på det personlige, er der ingen garanti for med denne løsning. Man kan sige, at identitetshåndteringen på sin vis bliver præget af kategorisering, da livshistorien bliver en slags ,etiket“, der bestemmer, hvordan personen, der lever med demens, kan blive mødt. Det fremmer således ikke nødvendigvis den værdighed, der er den overordnede ambition.

\section{Livshistorier som dynamiske virkelighedskonstruktioner}

Højlund og la Cour (2017) peger på, at teknologier bidrager til at „,fastlægge rutiner omkring intime og ikke-intime arbejdsopgaver, knyttet til at tage hånd om en gruppe (ofte sårbare) menneskers liv“ (op.cit.273). Livshistorier bidrager på samme måde til fastlæggelse af rutiner på den måde, at de giver medarbejderen en viden at handle ud fra. Denne viden kan, hvis den tjener et effektiviseringsformål, blive styrende og dermed betyde, at medarbejderen overser, hvad Højlund og la Cour kalder „væren“. Her afspejler livshistorien en hvilken som helst anden teknologi, og som Højlund og la Cour peger på, gør teknologien omsorg og liv muligt, men de risikerer samtidig at overse netop liv (op.cit.289). Når Højlund og la Cour taler om liv og væren, nærmer vi os aspekter, som rækker ud over historie og kategorier, og dermed kommer nutiden i fokus.

Personer, der lever med demens på et plejecenter, udfordrer på sin vis forestillinger om liv; de er, som Svendsen et al. (2018) peger på, i udkanten af livet i velfærdsstaten (op.cit.20). Men værdighedsmidlerne og det nye fokus på livshistorier peger i retning af en etisk fordring, som også bekræftes af flere af vores informanter. Livshistorien og med den det ,livshistoriearbejde“, hvis mål er at opretholde værdigheden hos personer, der lever med demens, skal opretholde mennesket ikke blot som et biologisk væsen, men også med identitet; en person med et autentisk selv. Identitetshåndteringen kommer til udtryk i arbejdet med livshistorien, når den danner grundlag for en pleje og omsorg, hvor den enkeltes vaner og interesser tages i betragtning, og hvor den enkelte mødes som et menneske med både en fortid og en nutid, men også en fremtid, hvor kortsigtet den end er. Hvis livshistorier skal fremme værdighed, skal de kunne hjælpe pleje- og omsorgsmedarbejdere til at nå disse mål og dermed understøtte grundlaget for værdighed. 
Gjødsbøl og Svendsen (2019) beskriver, hvordan der i arbejdet med personer, der lever med demens, bruges både den mere personlige livshistorie, fx hvor mange børn og børnebørn den enkelte har, og mere almene historiske kendsgerninger som $\mathrm{fx}$ begivenheder af betydning i den periode, den enkelte har levet. De peger dog også på, at der i mødet mellem pleje- og omsorgsmedarbejderen og personer, der lever med demens, kan indgå mere nutidige begivenheder. Gennem et studie af det konkrete møde leverer de et eksempel på, hvordan en medarbejder taler med den person, hun hjælper med påklædningen, om både hendes familie og den 9. april som en særlig dag. Derudover taler hun også med kvinden om begivenheder dagen før (op.cit.52). De viser altså, at selv om livshistorien kan være formet af historiske kendsgerninger, der placerer kvinden i „kategorier“ som mor eller husmor eller i dette tilfælde bedstemor, knyttes det til en situeret praksis, en dialog mellem de to parter, og bliver dermed et element i en samtale, der efter deres opfattelse er ,enactment“:

Ved at skabe forbindelse til aftenen før og træningssessioner de sidste dage såvel som til en signifikant dato i den danske historie, 'enacter' Hanne [medarbejder] Christine [personen, der lever med demens] som et menneske med en kollektiv såvel som en biografisk fortid og med en fremtid (op.cit.52).

Begrebet „enactment“ er svært at oversætte til dansk, hvorfor vi lader det være engelsk, men meningen her er, at livshistorien, selv om den bygger på kollektive og personlige facts, kan give mulighed for, at Christine kan træde frem og udleve sig selv, så at sige, som et menneske. Gjødsbøl og Svendsen (2019) skelner primært mellem de personlige og de kollektive facts, hvilket i lyset af identitetsspørgsmålet, som vi diskuterede ovenfor, kan genskabe en form for dialektik (Jenkins 2000), hvor eksterne begivenheder knyttes til, hvad man kunne kalde interne, i relation til identiteten.

Gjødsbøl og Svendsen (2019) omtaler desuden, hvordan mere aktuelle begivenheder inddrages i historien. På den måde viser de, hvordan også nutiden aktualiseres $i$ interaktionen, måske stadig med udgangspunkt $i$ en viden om, hvad der er Christines præferencer, hvilke aktiviteter hun glædes over. Sådanne begivenheder vil måske ikke være del af livshistorien, men bliver alligevel en del af den viden, pleje- og omsorgsmedarbejderen trækker på. Hun må dermed have kendskab ikke bare til Christines livshistorie, men også til de aktiviteter, der foregår i Christines nutid.

Felding (2018) har også foretaget feltarbejde på plejecentre i relation til implementering af teknologi. Hun beskriver i en rapport, at plejepersonalet har fokus på beboernes velbefindende. Hun påpeger, at dette fokus bygger på: 
Viden om den specifikke borgers fysiske og mentale helbred, viden om beboerens personlighed, livshistorie, og hvad hun godt kan lide og ikke kan lide og [...] om, hvordan hun reagerer i forskellige situationer (op.cit.11).

Her ser vi en bredde $i$, hvad det er for en viden, pleje- og omsorgsmedarbejderen har brug for, og ud over vaner og præferencer er der fokus på reaktioner på nutidige situationer.

Felding (2018) argumenterer for, at viden om den enkelte er afgørende for at yde omsorg på, hvad man kunne kalde en personcentreret måde (ibid.). Livshistorien kan således, sammen med andre videnselementer, tjene til identitetshåndtering hos personer, der lever med demens, og kan betragtes som en slags intervention, som potentielt kan forbedre kontakten mellem personalet og personer, der lider af demens, ved at de fastholdes som autentiske mennesker. For at et menneske, der lever med demens, reelt kan opleve sig selv som et autentisk selv, kræves det, at livshistorien anvendes som en slags stimulering eller som „enactment“, som Gjødsbøl og Svendsen (2019) taler om, suppleret af viden om, hvordan den enkelte reagerer i specifikke situationer, og ikke bare som et aftryk og kategorisering af, hvem den demente var engang.

I artiklen af Mileski et al. (2018) peges der på, at barndomsbilleder og musik er velegnede til at få den demente til at fortælle eller vippe rytmen med foden. På den måde kommer personer, der lever med demens, til at deltage i en interaktion med deres omverden. I vores empiri ses det også, hvordan et spil med billeder og lyde fra før i tiden er en stor succes og ,rigtig kunne få dem til at snakke“, som en af de interviewede medarbejdere sagde, før hun uddybede med dette udsagn om livshistorier:

Det giver tryghed hele vejen rundt. Så det er sådan planen, at vi skal bruge det fremadrettet. Og nogle steder, der har vi jo fået familien til at lave et, hvad hedder det ... Sådan ligesom et livstræ i billeder. Øh ... et fotoalbum, hvor de simpelthen har hentet helt fra begyndelsen af. Fra deres barndom og så hele vejen op igennem. Og så bruger vi tid på at sidde og bladre det igennem, og ... lægger nye billeder ind, når der sker noget nyt. Vi har lige haft besøg af Kiki, klovnen her. Som vi har taget nogle sjove billeder af, og så henter vi det frem. Det har været en god oplevelse, så snakker vi lidt om den. Og det giver rigtig stor pote, når de får trangen til at gå, vandre, ikke vide, hvor de er henne. Så kan vi ligesådan: Kan du huske dengang ...? Nu skal jeg hjælpe dig med at huske ... Og det giver rigtig meget. Især når man kan se på billeder. Så er det lige, som om at det gør det ægte.

Medarbejderen ser fordele i at arbejde ud fra livshistorien, som hun kan få til at „give pote“, når personer, der lever med demens, bliver urolige og vandrer rundt uden at vide, hvor de er. Citatet viser dog også, at livshistorien, her omtalt som et livstræ i billeder, kan tilføjes billeder fra nutiden og således ikke kun er fortid. På 
den måde flettes nutid og fortid sammen og bidrager til fremtiden. Her er det dog ikke længere med indflydelse fra de pårørende. Man kan sige, at personalet her har overtaget historieskrivningen eller det, som vi med vores teoretiske udgangspunkt kunne kalde virkelighedskonstruktionen. Det er også en pointe for Gjødsbøl og Svendsen (2019), at mens historien for pårørende til personer, der lever med demens, så at sige stopper ved indflytningen på plejecenteret, er det lige præcis der, den begynder for personalet, som arbejder både for at opretholde biologiske funktioner, så langt det kan lade sig gøre, og for at skabe „stjernestunder“ for den enkelte. Dermed kan livshistorien, hvis den fortsættes og er dynamisk, bidrage til, at personer, der lever med demens, mødes med værdighed.

\section{Konklusion}

Her vil vi samle artiklens pointer op ved at sammenligne livshistorien med de teknologier, som var centrale for det fokus, vi havde under feltarbejdet. Som omtalt $i$ indledningen har vi haft det omsorgsteknologiske perspektiv som en slags baggrund i vores analyse for at arbejde med andre teoretiske perspektiver, der kan være med til at folde betydninger af livshistorien ud i forhold til værdighed. Som det fremgår, bliver livshistorien ikke et „quickfix“ til værdighed, og på den måde holder den måske ikke helt, hvad den lover. Her minder den som løsning om mange af de teknologier, der indgik i vores undersøgelse.

Vi undersøgte, hvordan teknologier får betydning i pleje- og omsorgspraksis, og hvordan de i lyset af begrebet om omsorgsteknologi potentielt kan fremme relationer mellem personer, der lever med demens, og pleje- og omsorgsmedarbejderne og måske endda skabe forandring i den praksis og dermed kulturelle sammenhæng, de indgår i. Vi så, hvordan nogle teknologier blev brugt temmelig instrumentelt, mens andre blev brugt med større refleksion og opmærksomhed på situationen og den enkelte borger.

Livshistorien bliver taget $i$ anvendelse efter nogenlunde samme skabelon. Når den bruges som det, vi har kaldt et aftryk af mennesket, kan man argumentere for, at den bliver mere instrumentel på den måde, at kendskab til livshistorien danner grundlag for at yde pleje og omsorg uden helt at komme i spil på en dynamisk måde. Når den anvendes som en seddel på døren med de tre vigtigste ting, former den opgaven ved at lægge en slags ramme om denne, men den påvirker ikke nødvendigvis omsorgen som en relationel proces. I lyset af det omsorgsteknologiske perspektiv bliver det dog også klart, at der sker en tilpasning mellem livshistorier og den praksis, der præger plejecentrets organisering, som udfolder sig som en spænding mellem den opgavecentrerede og personcentrerede tilgang. Dermed bliver livshistorien taget $\mathrm{i}$ anvendelse på en særlig reduceret måde, der 
får betydning i forhold til identitetshåndtering og virkelighedskonstruktion og fletter sig ind i eller medierer samspillet mellem pleje- og omsorgspersonalet og personen, der lever med demens. Omsorgen kommer således til, på pragmatisk vis, at handle om at få tingene til at fungere, at tilpasse og indordne. Livshistorien og den analyse, vi har leveret om den, er et eksempel på, hvordan politiske ambitioner og dermed også økonomiske midler ikke bare styrer hverdagens praksis, men også bidrager til en dynamisk udvikling af handleviden, der kombinerer praktiske ambitioner - om at møde personer, der lever med demens, som andet og mere end en tom skal - med organisering af arbejdet.

I vores analyse bliver identitetshåndtering eller fastholdelsen af det autentiske selv til et udtryk for værdighed, og det, vi har kaldt „livshistoriearbejde“, bliver selve den mediering, som livshistorien skaber. Vi har valgt ikke at definere eller diskutere begrebet værdighed, men i stedet bruge det, der trådte frem gennem analysen af empirien, til at forstå begrebet, og det, der toner frem, er værdighed som noget relationelt snarere end noget, „man har", som noget, vi som mennesker kan give hinanden i interaktionen med hinanden.

Vi har ovenfor belyst, hvordan livshistorien kan få betydning for, hvordan den enkelte medarbejder møder personen, der lever med demens, og hvordan den har potentiale til at skabe rum for dem, ikke bare som mennesker med en fortid, men som mennesker, der er i nutiden og kan inddrages i en dialog, hvis livshistorien anvendes på en situeret og dynamisk måde. Når livshistorien anvendes som en måde at stimulere hukommelse og social forankring på såvel som et udgangspunkt for omsorgsrelaterede handlinger, kan den bidrage til værdighed. Når det lykkes personalet at „enacte“ og skabe stjernestunder ved hjælp af livshistorien, skabes der netop en sammenhæng mellem fortid, nutid og fremtid. Og personer, der lever med demens, konstrueres, ikke som et resultat af livshistorien som et deterministisk instrument, men i relationen til pleje- og omsorgsmedarbejderne. På den måde skabes der rum for den væren, som i analysen kommer til at stå centralt i forhold til værdighed.

\section{Note}

1. Empirien, som denne artikel bygger på, stammer fra feltarbejde på to plejecentre $\mathrm{i}$ to forskellige kommuner i 2016-2017, hvor vi gjorde brug af både deltagerobservation og formelle og uformelle interviews (Hastrup 2004; Fangen 2010). Der indgår 13 dages feltnoter i den samlede empiri, baseret på ophold på plejecentre og uformelle samtaler med både personale og beboere. Vi har opholdt os i fællesrum og har besøgt enkelte af beboerne i deres bolig. Vi har ikke deltaget i planlagte pleje- og omsorgsopgaver. Vi udførte desuden ni semistrukturerede interviews med pårørende og 13 med ansatte, der alle har givet samtykke til at deltage i projektet, og interviewene blev transskriberet. Vi valgte ikke at udføre formelle interviews med beboerne, der lever med demens, men gennem uformelle samtaler med dem under vores 
deltagerobservation blev vi i et vist omfang indviet $i$, hvad det vil sige at leve med demens og at bo på et plejecenter. Analysen af empirien er empiristyret og fænomenologisk inspireret (Giorgi 2009), hvilket afspejles i overskrifter på de analytiske afsnit i artiklen, som er udtryk for de temaer, vi identificerede i den analytiske proces.

\section{Litteratur}

Bjelland, Anne Karen

2014 Fortid og felleskap. Identitetshåndtering blandt eldre i aldersboliger. Norsk Antropologisk Tidsskrift 25(2):81-93.

Brownie, Sonya \& Louise Horstmanshof

$2012 \quad$ Creating the Conditions for Self-Fulfilment for Aged Care Residents. Nursing Ethics 19(6):777-86. https://doi/10.1177/0969733011423292.

Cooney, Adeline \& Eamon O'Shea

2019 The Impact of Life Story Work on Person-Centred Care for People with Dementia Living in Long-Stay Care Settings in Ireland. Dementia 18(7-8):2731-46. https: //doi.org/10.1177/1471301218756123.

Craig, Jacqueline

2014 Music Therapy to Reduce Agitation in Dementia. Nursing Times 110(32-33):1217.

Fangen, Katrine

2010 Deltagende observasjon. Bergen: Fakbokforlaget.

Felding, Simone Anna

2018 Demensteknologier i praksis. Antropologisk Analyse. Institut for Antropologi.

København: Københavns Universitet.

Giorgi, Amedeo

2009 The Descriptive Phenomenological Method in Psychology. A Modified Husserlian Approach. Pittsburgh, PA: Duquesne University Press.

Gjødsbøl, Iben \& Mette Svendsen

2019 Time and Personhood across Early and Late-stage Dementia. Medical

Anthropology 38(1):44-58. https://doi.org/10.1080/01459740.2018.1465420.

Gjødsbøl, Iben, Lene Kock \& Mette Svendsen

2017 Resisting Decay. On Disposal, Valuation, and Care in a Dementia Nursing Home in Denmark. Social Science \& Medicine 184:116-23. https://doi.org/10.1016/ j.socscimed.2017.05.022.

Hasse, Cathrine \& Jamie Wallace

2014 Omsorgsteknologier. I: L. Huniche \& F. Olesen (red.): Teknologi i sundhedspraksis. Side 83-103. København: Munksgaard.

Hastrup, Kirsten

2004 Introduktion. Den antropologiske videnskab. I: K. Hastrup (red.): Ind i verden. En grundbog i antropologisk metode. Side 9-33. København: Hans Reitzels Forlag.

Højlund, Holger \& Anders la Cour

2017 Om brugen af teknologier på plejehjem. I: M.P. Karlsen \& K. Villadsen (red.): Sundhed og magt. Side 269-99. København: Hans Reitzels Forlag. 
Jenkins, Richard

$2000 \quad$ Categorisation. Identity, Social Process and Epistemology. Current Sociology 48(3):7-25. https://doi.org/10.1177/0011392100048003003.

Kauffmann, Lene Teglhus \& Lone Holst Rosager

2019 Sundhedsfaglig praksis. Varme hænder og kold teknologi. Klinisk Sygepleje 33(4):

304-15. https://doi.org/10.18261/issn.1903-2285-2019-04-05.

Kitwood, Tom

2009 Introduction \& On Being a Person. In: T. Kitwood: Dementia Reconsidered.

The Person Comes First. Pp. 1-19. Maidenhead: Open University Press.

Mileski, Michael et al.

2018 Sensory and Memory Stimulation as Means to Care for Individuals with Dementia in Long Term Care Facilities. Clinical Interventions in Aging 13:967-74. https: //doi.org/10.2147/CIA.S153113.

Moyle, Wendy et al.

2011 Factors Influencing Quality of Life for People with Dementia. A Qualitative Perspective. Aging \& Mental Health 15(8):970-77. https://doi.org/10.1080/ 13607863.2011.583620.

Nielsen, Anne Kerstine Rørbye

2017 Kroppe uden personer? En antropologisk undersøgelse af personopfattelse og demens på et plejehjem i Danmark. Speciale. Institut for Antropologi. København: Københavns Universitet.

Pedersen, Ina Kjøgx

2018 Drengen der blev væk. Mor, mig og demensen. København: Gyldendal.

Simonhjell, Nora \& Ingvill Hellstrand

2019 „De skrev henne ned.“ Livsarket og fortellinger om identitet og omsorg. Tidsskrift for omsorgsforskning 5(2):1-14. https://doi.org/10.18261/issn.2387-5984-2019-0203 .

Skjødt, Ulla

2016 Ældreliv i plejebolig. Et studie af ældres autonomi- og livssituation i den politiske tilrettelæggelse af plejeboligens rammer. Ph.d.-afhandling, Afdeling for Filosofi og Idehistorie. Aarhus: Aarhus Universitet.

2019 Standardisering som redskab til organisering af sygepleje i det nære sundhedsvæsen. I: U. Skjødt \& I. Jekes (red.): Sygepleje som professionsfelt i det nære sundhedsvæsen. Side 23-39. København: Gads Forlag.

2020 Ældreliv i den politiske tilrettelæggelse af boliger til svækkede ældre. Et historisk perspektiv. I: S. Glasdam \& F.F. Jacobsen (red.): Gerontologi. Side 38-54.

København: Gads Forlag.

Sundheds- og Ældreministeriet

2016 Et trygt og værdigt liv med demens. Oplæg til den nationale demenshandlingsplan 2025. København: Sundheds- og Ældreministeriet.

Sundhedsstyrelsen

2017 Livshistorier skal forbedre dementes hverdag. https://www.sst.dk/da/nyheder/ 2017/livshistorier-skal-forbedre-dementes-hverdag. Læst 27.8.2020.

2019 Videnscenter for værdig ældrepleje. https://www.sst.dk/da/opgaver/videnscenterfor-vaerdig-aeldrepleje. Læst 25.8.2020. 
Svendsen, Mette N., Laura E. Navne, Iben M. Gjødsbøl \& Mie S. Dam

2018 A Life Worth Living. Temporality, Care, and Personhood in the Danish Welfare

State. American Ethnologist 45(1):20-33. https://doi.org/10.1111/amet.12596.

Tyler, Jeanelle

2017 Engaging with Dementia. Moral Experiments in Art and Friendship. Cultural Medicine and Psychiatry 41:284-303.

Vink, Annemieke et al.

2013 The Effect of Music Therapy Compared with General Recreational Activities in Reducing Agitation in People with Dementia. A Randomized, Controlled Trial. International Journal of Geriatric Psychiatry 28(10):1031-38. https://doi.org/ $10.1002 / \mathrm{gps} .3924$. 